\title{
Foveal haemorrhage from makeshift 'Lightsaber': funduscopy and optical coherence tomography findings
}

Damien Chia Ming Yeo, ${ }^{1}$ Charles Osei-Bempong, ${ }^{2}$ Amylee Shirodkar, ${ }^{3}$ Gwyn Samuel Williams ${ }^{3}$

${ }^{1}$ Department of Ophthalmology, Singleton Hospital, Swansea, UK ${ }^{2}$ Singleton Eye Unit, Singleton Hospital, Swansea, UK

${ }^{3}$ University Hospital of Wales, Cardiff, UK

\section{Correspondence to} Damien Chia Ming Yeo, cm.yeo@doctors.org.uk

Accepted 28 February 2016

CrossMark

To cite: Yeo DCM, OseiBempong C, Shirodkar A, et al. BMJ Case Rep Published online: [please include Day Month Year] doi:10.1136/bcr-2016214711

\section{DESCRIPTION}

A 15 -year-old boy presented after being attacked by a 'Lightsaber' wielded by his friend. The device in question was a blue laser pointer $(450 \mathrm{~nm}$ $8000 \mathrm{~mW}$ ) reflected by his friend off a mirror-the beam caught the patient in the left eye for a mere 1 or $2 \mathrm{~s}$. His vision dropped immediately and he presented the next day with a macular haemorrhage (figure 1) and a vision of $6 / 60$. We treated via observation only and, fortunately, his vision improved slowly over the next 4 weeks: day 7 , $6 / 36$; day $14,6 / 18$ and day $30,6 / 12$. In the absence of any evidence for an active choroidal neovascular membrane, we felt that intravitreal antivascular endothelial growth factor therapy was not indicated.

It is common knowledge that lasers can cause retinal injury, ${ }^{1}$ but we would like to share these

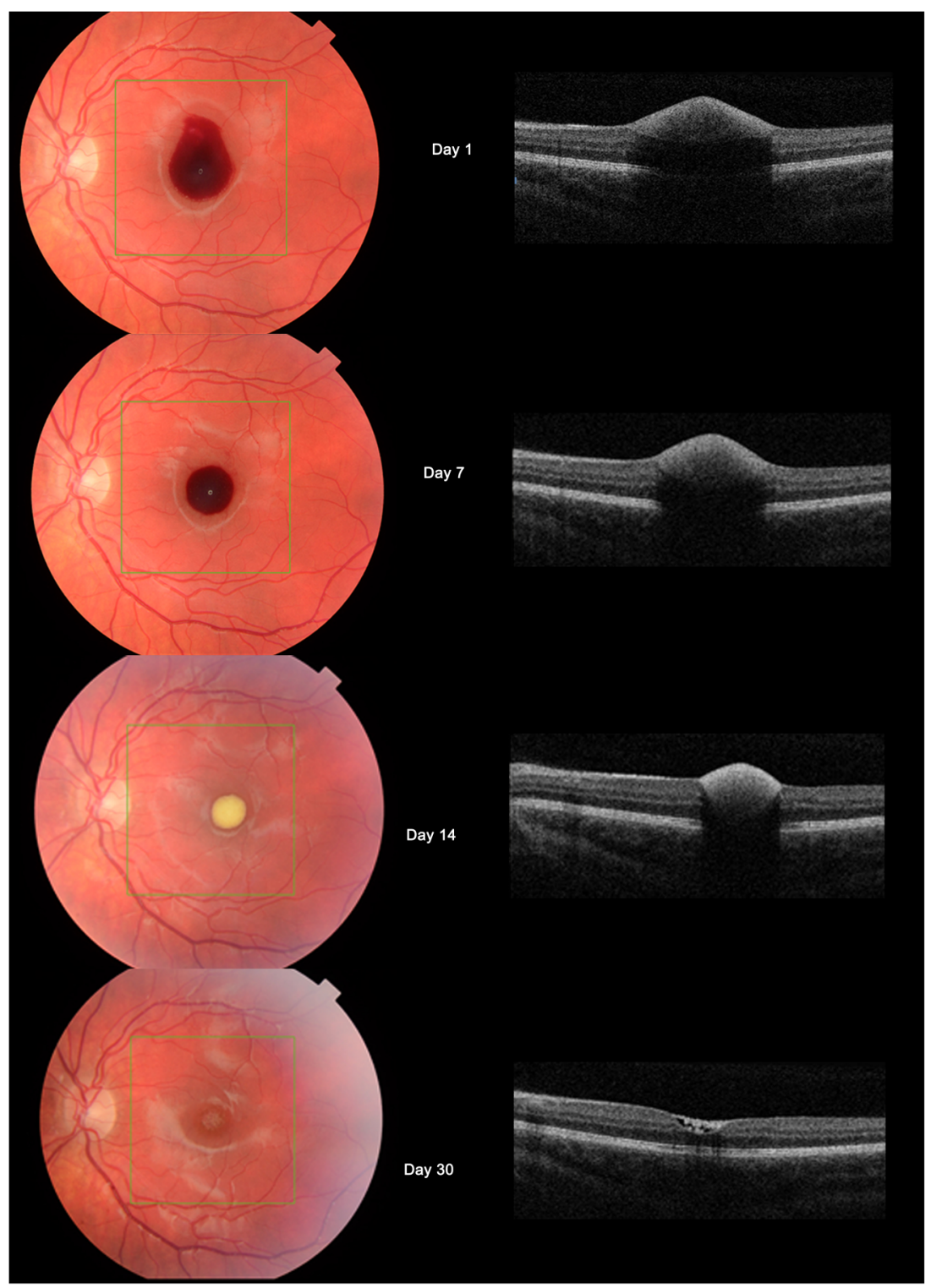

Figure 1 Fundus photos and optical coherence tomography images capturing the natural history of the foveal haemorrhage following the laser injury. 
images depicting the natural progression of a foveal haemorrhage.

High-powered lasers are now even more readily available off the internet. ${ }^{2}$ Unlike those normally seen in the classroom or

\section{Learning points}

- We recommend careful observation for these patients in the short term as surgical treatment may carry more risk especially if the underlying subretinal structure is not seen.

- High-powered laser devices are getting very accessible. The public should strictly keep these away from children.

- These pictures capture the natural history of a foveal haemorrhage secondary to laser injury that will settle slowly with time. We wish to share these images to be used as reference for future cases of suspected laser retinal injury. office setting, which are usually about $5 \mathrm{~mW}$ or less, ${ }^{3}$ these $8000 \mathrm{~mW}$ lasers can burn skin, cause fires and even light cigarettes. Anyone can purchase one of these unregulated devices for a very low cost and do irreversible damage to vision with minimal effort. The sale of these devices should be made illegal to the general public as it has potential to cause significant bodily harm even from quite a distance away.

Competing interests None declared.

Patient consent Obtained.

Provenance and peer review Not commissioned; externally peer reviewed.

\section{REFERENCES}

1 Mainster MA, Stuck BE, Brown J Jr. Assessment of alleged retinal laser injuries. Arch Ophthalmol 2004;122:1210-7.

2 Wyrsch S, Baenninger P, Schmid M. Retinal injuries from a handheld laser pointer. N Engl J Med 2010;363:1089-91.

3 Ajudua S, Mello MJ. Shedding some light on laser pointer eye injuries. Pediatr Emerg Care 2007;23:669-72.

Copyright 2016 BMJ Publishing Group. All rights reserved. For permission to reuse any of this content visit

http://group.bmj.com/group/rights-licensing/permissions.

BMJ Case Report Fellows may re-use this article for personal use and teaching without any further permission.

Become a Fellow of BMJ Case Reports today and you can:

- Submit as many cases as you like

- Enjoy fast sympathetic peer review and rapid publication of accepted articles

- Access all the published articles

- Re-use any of the published material for personal use and teaching without further permission

For information on Institutional Fellowships contact consortiasales@bmjgroup.com

Visit casereports.bmj.com for more articles like this and to become a Fellow 